\title{
The Influence of Commercial Banks in Financing Small and Medium Enterprises (SMEs) in Nigeria: A Case Study of Fidelity Bank Plc and First Bank of Nigeria Plc in Ibadan Metropolis
}

\author{
Agbebi Moses Olusola, Murtadho. M. Alao, Amiya Bhaumik
}

\begin{abstract}
This study investigated the influence of commercial banks in financing small and medium scale enterprises in Nigeria to determine the extent to which SMEs access relevance services and credit facilities from Fidelity and First banks as well as their contributions to economic growth in Ibadan metropolis. Descriptive research design was adopted. Purposive sampling technique was used to sample 200 owners of SMEs in Oluyole Local Government Area of Oyo state. Data collected were analysed using frequency counts, simple percentage score and regression analysis.

The study showed that only $9.37 \%$ of the respondents had access to the banking services whereas $37.1 \%$ had no access to the banking services being provided by Fidelity and First banks in Ibadan metropolis. From the findings, $2.3 \%$ of the respondents strongly agreed that they obtained loans frequently whereas $32.1 \%$ strongly disagreed; $8 \%$ of them strongly agreed that bank charges on loans are moderate and affordable $38.9 \%$ refuted the position. The findings generally revealed that SMEs do not have adequate access to loan facilities from the commercial banks. It is therefore recommended that commercial and microfinance banks should offer financial services like credit facilities at moderate rate of interest with less stringent conditions to SMEs to grow their businesses and generate more employment within the economic hub of the country.
\end{abstract}

Index Terms - credit facilities, Fidelity bank, First bank, service, Small and medium enterprises.

\section{INTRODUCTION}

Small and Medium Enterprises (SMEs) play significant roles in all economies. They are crucial to economic growth and development in both industrialized and developing countries. SMEs play key functions in job creation, innovation and creativity. They constitute a larger percentage of private sector in many developed and developing countries. According to Organisation for Economic Cooperation and Development (OECD) countries (2019), SMEs account for $99 \%$ of all businesses and between $50 \%$ and $60 \%$ of value added. SMEs create between $60 \%$ and $70 \%$ jobs in any economy. Small businesses assist in bringing innovative products or techniques to the market.

There is no universally accepted definition of Small and Medium Enterprises (SMEs). Its definition varies from one country to another depending on the state of their economic development and country specific legislation with their

Agbebi Moses Olusola, Lincoln University College, Malaysia

Murtadho. M. Alao, Deputy Regisrar, Lincon University College, Malaysia Amiya Bhaumik, President Lincoln University College, Malaysia prevailing social conditions. European Commission, (2016a), defined SMEs as micro-enterprises which employees less than ten with annual turnover below $€ 2$ million whereas enterprises with less than 50 employees and annual turnover of less than $€ 10$ million are classified as small enterprises. Medium-sized enterprises are those that employ less than 250 employees with annual turnover of less than $€ 50$ million. According to Leopoulos, (2006) SMEs is categorized by National Small Business Act 102 of 1996 in South Africa, as amended by Act 29 of 2004 as small organizations. They grouped them into four categories namely: micro enterprises including survivalist enterprises; very small enterprises; small enterprises; and medium enterprises.

Ayyagari, (2007) opined that the definition of SMEs depends on the indexes used such as number of employees, invested capital, total amount of assets, sales volume (turnover) and production capacity. In modern economies small and medium-sized enterprises (SMEs), typically employ between 10 and 250 workers,

The inability of SMEs to adopt new technologies and innovations is the major challenge to the survival of their businesses. This might not be unconnected with inadequate capital to finance their businesses. Although, there seems to be several potential sources of finance to SMEs such as personal savings, soft loans from friends, relations, cooperative societies, loans from financial institutions like commercial banks and microfinance banks. These sources in most cases, are meagre and usually from personal savings, soft loans from friends, relations and cooperative societies. The major challenge to SMEs is their inability to access better sources of finance from commercial banks.

Notable among the challenges are high interest rates, nonavailability of collateral security and highly bureaucratic loan procedures. It is also observed that most SMEs do not patronize many of the products offered by the financial institutions. They do not often obtain credit facilities from financial institutions such as commercial banks. This could be due to factors such as stringent conditions set by these financial institutions when SMEs approach them for credit facilities.

Generally, commercial banks are established as a povertyfighting instrument in order to achieve sustainable economic growth and development. They are expected to provide adequate finance services in form of loans and advances to small and medium businesses. However, within 
the knowledge of the researchers, studies have not shown that commercial banks have derived appreciable benefits from micro-businesses than the benefits the micro-businesses gain from them which could be due to the high interest rates on loans and short term repayment period. Further, inadequate financial management training, high interest rates, short term repayment period on loans and advances, and mismanagement credit facilities to SMEs could also serve as major obstacles to commercial banks in providing credit facilities to SMEs. This study therefore attempts to investigate the extent to which SMEs access financial services especially loans and advances from commercial banks in order to grow their businesses in Ibadan metropolis and offer solutions on how SMEs will increase their capital base, profitability and overall efficiency.

\section{STATEMENT OF THE PROBLEM}

Despite several potential sources of finance that seems to be available to small and medium enterprises to expand their businesses in Nigeria, it appears that SMEs are finding it difficult to access credit facilities and other financial services from the commercial banks. This could be due to stringent conditions attached to accessing credit facilities to finance their business operations. Such challenges could include high interest rate, inability to provide legal and economically viable property as collateral on loans and advances and stringent bureaucratic loan procedures. This suggests that SMEs do not have sufficient access to the financial services especially loans and advances being offered by the commercial banks in Nigeria to finance their business operations. This study therefore attempts to investigate the extent to which SMEs access the financial services especially loans and advances being offered by the commercial banks in Ibadan metropolis, Oyo state, Nigeria with the aim of providing solution to improving their sources of finance.

\section{OBJECTIVES OF THE STUDY}

This study is designed to investigate the influence of commercial banks on small and medium enterprises (SMEs) in Ibadan metropolis. The following specific objectives will be achieved by this study:

i. To examine the extent to which SMEs access relevant services from

Fidelity and First banks in Ibadan metropolis; ii. To investigate the level at which SMEs obtain credit facilities from the selectedcommercial banks in Ibadan metropolis.

iii.To determine the extent to which commercial banks have contributed to SMEs growth in Ibadan metropolis.

\section{A. Research Questions}

The following research questions were answered in this study:

i. To what extent do SMEs access relevant financial services being offered by Fidelity and Fitst bank, Ibadan?

ii. How frequent do SMEs obtain credit facility from Fidelity and First banks in Ibadan?

\section{B. Hypothesis}

$\mathrm{H}_{1}$ : There is no significant relationship between access to loan facilities and business growth of SMEs in Ibadan metropolis.

\section{LITERATURE REVIEW/THEORETICAL UNDERPINNINGTHE CONCEPT AND RELEVANCE OF SMALL AND MEDIUM SCALE ENTERPRISES (SMES)}

The definition of SMEs varies from one country to another depending on the level of economic development, country specific legislation and their prevailing social conditions. According to European Commission, (2016a), SMEs are micro-enterprises which employees are less ten with annual turnover below $€ 2$ million. Whereas enterprises with less than 50 employees and annual turnover of less than $€ 10$ million are classified as small enterprises. Medium-sized enterprises are those that employ less than 250 employees with annual turnover of less than $€ 50$ million. According to Leopoulos, (2006) SMEs is categorized by National Small Business Act 102 of 1996 in South Africa, as amended by Act 29 of 2004 as small organizations. They grouped them into four categories namely: micro enterprises, including survivalist enterprises; very small enterprises; small enterprises; and medium enterprises. Von Broembsen, (2003) asserted that the number of employees is one of the criteria for differentiating these categories of businesses, apart from micro enterprises. The level of turnover is the criterion used for micro enterprises.

Ayyagari, (2007) opined that the definition of SMEs depends on the indexes used such as number of employees, invested capital, total amount of assets, sales volume (turnover) and production capability. SMEs constitute a large percentage of private sector in many developed and developing countries. Mina and Hughes, (2013), opined that the definition and criteria for classification of an enterprise as small, medium or large varies from one country to another, depending on whether it is a developed or developing country. In Nigeria, SMEs is defined as an enterprise whose total capital employed is between N1.5 million and N200 million excluding cost of land and with staff strength between 10 and 300. Small and medium enterprises play significant role in production, employment generation, promotion of exports and enhancement of equitable distribution of income. SMEs contribute significantly to increase in gross domestic product (GDP) through small and medium scale manufacturing companies. They serve as important tool for mitigating against the problem of imbalance in the balance of payment accounts.

Kadiri (2012) argued that SMEs serves as a catalyst for employment creation, national growth, poverty alleviation and economic development. It is a major employer of labour when compared to the major industries including the multinationals in the world. According to Oluba (2009) in Olorunfemi and Olajide (2014) SMEs play important role in greater utilization of raw materials, employment generation, promotion of rural development, development of entrepreneurship, mobilization of local savings, linkages with bigger industries, provision of regional balance by spreading investments more evenly, provision of avenue for self-employment and provision of opportunity for training managers and semi-skilled workers. 
Small and medium enterprises operate very close to their customers with some degree of openness in the way they carry on their business activities. This makes it possible for them to adapt to the changes in their business environment. Friedrich, 2004 and Watson, (2004) in Yolande and Watkins (2012) identified the unique role of SMEs in employment creation and economic growth, especially in developing countries like South Africa with a high rate of unemployment of about $40 \%$.

Olukayode and Somoye, (2013) investigated the impact of finance on entrepreneurship growth in Nigeria using endogenous growth framework. Their findings revealed that finance, interest rate, real gross domestic product, unemployment and industrial productivity are important to entrepreneurship development in Nigeria. The results further indicated a unidirectional Granger causal relationship and suggest that access to finance by entrepreneurship has significant relationship with economic growth in Nigeria. The study therefore suggested the formulation of effective macroeconomic policy aimed at entrepreneurship financing and growth. The findings further recommended that monetary authorities should intervene indirectly by reducing monetary policy rates (MPR) which will directly reduce the transaction costs of funds to entrepreneurship and industrial sectors. The study concluded that the central authority should create an enabling environment for SME development.

Onakoya, Fasanya and Abdulrahman (2013) carried out a study on the impact of financing small scale enterprises on economic growth using quarterly time series data from 1992 to 2009. The study showed that loan to small scale entrepreneurs have a positive impact on the economic performance and concluded that access to capital or finance is necessary but not a sufficient condition for successful entrepreneurial development.

\section{ACCESS TO LOAN/FINANCE AND SMES PERFORMANCE}

Access to finance according to Demirguc-Kunt, Beck and Honohan,(2008) has to do with the possibility that individuals or enterprises would make use of financial services, including credit, deposit, payment, insurance and other risk management services. They further stressed that access to finance is different from the actual use of financial services because use of financial service is voluntary. Voluntary non-users of financial services have access to but do not use financial services either because they have no need for those services or because they decided not to make use of such services due to cultural, religious or other reasons. Access to finance is broader than usage. Usage has the advantage of being directly observable. However, it is argued that the consumption or use of financial services (users of The table below shows the extent to which SMEs access relevant financial services from Fidelity bank and First bank in Ibadan Metropolis.

\begin{tabular}{|c|c|c|c|c|c|}
\hline & 1 & 2 & 3 & 4 & $\%$ of responses \\
\hline $\begin{array}{l}\text { How often do you feel your bank offer you the best } \\
\text { products for your business apart from loans? }\end{array}$ & 8.4 & 13 & 36.6 & 42 & 100 \\
\hline $\begin{array}{l}\text { How often do you get other relevant services from your } \\
\text { bank for the growth of your business? }\end{array}$ & 7.6 & 17.6 & 38.9 & 35.9 & 100 \\
\hline $\begin{array}{l}\text { How frequent do banks quickly rectify problems with you } \\
\text { as a customer? }\end{array}$ & 10.7 & 24.4 & 32.8 & 32.1 & 100 \\
\hline $\begin{array}{l}\text { How often do bank employees do follow up on your } \\
\text { business matter? }\end{array}$ & 22.1 & 26 & 37.4 & 14.5 & 100 \\
\hline $\begin{array}{l}\text { How often do your bank solve business related problems } \\
\text { for you? }\end{array}$ & 13 & 14.5 & 29 & 43.5 & 100 \\
\hline $\begin{array}{l}\text { How much do your bank offer you the best of customer } \\
\text { relations? }\end{array}$ & 2.3 & 20.6 & 45 & 32.1 & 100 \\
\hline $\begin{array}{l}\text { How often are you satisfied with the services rendered by } \\
\text { the bank? }\end{array}$ & 1.5 & 6.9 & 32.1 & 59.5 & 100 \\
\hline $\begin{array}{l}\text { Average in percentage of the extent to which SMEs access } \\
\text { relevant banking services being provided by } \\
\text { Fidelity and First banks in Ibadan }\end{array}$ & 9.37 & 17.6 & 36 & 37.1 & 100 \\
\hline
\end{tabular}


financial services) may not be equivalent to access to such services, as there is a group of persons or firms who voluntarily exclude themselves from consumption. Thus, the group with access would be greater than the group of current consumers of financial services, and would be defined by users of financial services and voluntary exclusion Kumar, (2005b).

Ofili (2014) adopted qualitative research methodology to evaluate the challenges facing entrepreneurship in Nigeria. The study discovered that policies formulated by the government are such that do not promote the growth of small and medium enterprises.

\section{METHODOLOGY}

This study adopted descriptive research design. It focused on SMEs that use the financial services of two major commercial banks; Fidelity bank Plc and First bank plc. The population of this study comprises SMEs owners of cottage, wholesale and retail businesses in Ibadan metropolis. Purposive sampling technique was used to sample 200 respondents from SMEs operating in Oluyole Local Government Area Ibadan, Oyo state, Nigeria. Descriptive statistical tools such as frequency and simple percentage score as well as regression analysis were used for data analysis.

\section{RESULTS/DISCUSSION OF FINDINGS}

Research question one: To what extent do SMEs access relevant financial services being offered by Fidelity bank and First bank in Ibadan metropolis?

Keys: 1 - More frequently, 2 - Frequently, 3 - Less frequently, 4 - Non-frequently. The above table presents the results of the extent to which the owners of SMEs access and enjoy the financial services being provided by Fidelity and First banks in Ibadan metropolis. The study showed that only $9.37 \%$ of the respondents had access to the financial services whereas $37.1 \%$ of the respondents indicated that they did not have access to the services being provided by the banks. The findings of this study are in accordance with the findings of Ofili (2014) and Ferreira, Azevedo, and Ortiz, (2011) that attitude, characteristics, good record keeping, and financial control could hinder SMEs from accessing finance commercial banks.

Research question two: How frequently do SMEs obtain credit facilities from Fidelity bank and First bank in Ibadan metropolis?

The table below shows the Extent to Which SMEs Access Credit Facilities from First bank and Fidelity Banks in Ibadan metropolis?

Source: 2019 field survey

Keys: 1 - Strongly Agreed, 2 - Agreed, 3 - Disagreed, 4 - Strongly disagreed

From the above table, $2.3 \%$ of the respondents strongly agreed that they obtained credit facilities from the banks frequently, whereas $32.1 \%$ strongly disagreed that they obtained credit facilities frequently from the banks. Also $8 \%$ of respondents strongly agreed that bank charges on credit facilities are moderate and affordable whereas $38.9 \%$ indicated that bank charges on credit facilities are unaffordable. Further, $23.7 \%$ of the respondents revealed that special loan facilities to boost their SMEs are made available to them. The findings of this study generally revealed that SMEs do not have adequate access to credit facilities from the commercial banks. This is in agreement with the findings of Ofili (2014) that the challenge facing Nigerian SMEs is the danger of appraising enterprises by their financiers of the level and nature of pledges (collateral security) they can give for the loans and also their past turnover, current resource base, age of the firm.

\begin{tabular}{|c|c|c|c|c|c|}
\hline & 1 & 2 & 3 & 4 & $\begin{array}{c}\% \text { of } \\
\text { response }\end{array}$ \\
\hline get loans often from my bank & 2.3 & 16.8 & 48.9 & 32.1 & 100 \\
\hline Charges on obtained loans are sometimes made affordable & 0.8 & 8.4 & 51.9 & 38.9 & 100 \\
\hline tend to obtain loan without much choice & 2.3 & 10.7 & 49.6 & 37.4 & 100 \\
\hline Often times than not, I get preferential loan approval & 12.2 & 26 & 44.3 & 17.6 & 100 \\
\hline $\begin{array}{l}\text { There are available special loan facilities for me as an } \\
\text { SME owner }\end{array}$ & 23.7 & 40.5 & 26.7 & 9.2 & 100 \\
\hline
\end{tabular}

\section{A. Hypotheses}

is presented on the table below:

There is no significant relationship between access to loan facilities and business growth of SMEs in Ibadan metropolis. This was tested using linear regression analysis and the result 


\begin{tabular}{|l|l|l|l|c|}
\hline Model & $\mathrm{R}$ & $\begin{array}{l}\mathrm{R} \\
\text { Square }\end{array}$ & $\begin{array}{l}\text { Adjusted } \\
\mathrm{R} \\
\text { Aquare }\end{array}$ & $\begin{array}{l}\text { Std. Error of the } \\
\text { Estimate }\end{array}$ \\
\hline 1 & $0.971^{\mathrm{a}}$ & 0.943 & 0.941 & 1.18162 \\
\hline
\end{tabular}

a.Dependent Variable: business growth

qualification, years in business, access to loan facilities.

a.Predictor: (constant), number of employees, educational Dependent Variable: Business growth

\begin{tabular}{|l|l|l|l|l|c|}
\hline Model & $\begin{array}{l}\text { Sum of } \\
\text { Square }\end{array}$ & Df & F & Sig \\
\hline & $\begin{array}{l}2891.679, \\
175.924,\end{array}$ & & 722.920 & 517.769 & $0.000^{\mathrm{b}}$ \\
1 & 3067.603 & 126 & & \\
$\begin{array}{l}\text { Regression, Residual, } \\
\text { Total. }\end{array}$ & & 130 & & \\
\hline
\end{tabular}

\section{ANOVA}

a.Dependent Variable: business growth

b.Predictor: (Constant) number of employees, educational qualification, years in business, access to loan facilities.

\section{Coefficients.}

a.Dependent Variable: business growth.

The above table showed the results on the joint and independent influence of access to loan facilities in commercial banks and other factors on business growth of SMEs owners. The findings of this study showed that access to loan facilities, educational qualification, years in business and number of employees jointly predicted business growth
$[\mathrm{F}(4,126)=517.769 ; \mathrm{P}<.01]$. Further, access to loan facilities, educational qualification, years in business and number of employees accounted for about $94.3 \%$ variance in business growth.

However, as regards independent influence, only access to loan facilities from commercial banks had significant independent influence on business growth $(\beta=.97 ; \mathrm{t}=$ 44.383; $\mathrm{P}<.01)$. This is in agreement with the findings of Olukayode and Somoye, (2013) that access to finance by entrepreneurship has significant relationship with economic growth in Nigeria.

\begin{tabular}{|c|c|c|c|c|c|c|}
\hline \multicolumn{2}{|c|}{ Model } & $\begin{array}{l}\text { Unstandardized } \\
\text { Coefficients }\end{array}$ & $\begin{array}{l}\text { Std. } \\
\text { Error }\end{array}$ & $\begin{array}{l}\text { Standardized } \\
\text { Coefficients } \\
\text { Beta }\end{array}$ & $\mathrm{t}$ & Sig. \\
\hline 1 & $\begin{array}{l}\text { (Constant) } \\
\text { Access loan facilities } \\
\text { Educational qualification } \\
\text { Years in business } \\
\text { Number of employee }\end{array}$ & $\begin{array}{l}.609 \\
1.547 \\
-.004 \\
.045 \\
.046\end{array}$ & $\begin{array}{l}.656 \\
.035 \\
.129 \\
.167 \\
.110\end{array}$ & $\begin{array}{l}.970 \\
-.001 \\
.006 \\
.009\end{array}$ & $\begin{array}{l}.928 \\
44.383 \\
-.027 \\
.267 \\
.417\end{array}$ & $\begin{array}{c}.355 \\
.000 \\
.978 \\
.790 \\
.677\end{array}$ \\
\hline
\end{tabular}

\section{CONCLUSIONS}

The foregoing conclusions were drawn from the findings of the study;

The respondents indicated that they do not patronize commercial banks (Fidelity and First banks) frequently. Also they did not access credit facilities from the banks frequently. Finally, most of the respondents indicated that bank charges on credit facilities and other financial services are high and unaffordable.

\section{A. Implication to Research and Practice}

This study is conducted to fill gaps in the literature on small and medium enterprises (SMEs) access to financial services of commercial banks especially credit facilities for business growth. The findings of this study will be relevant to the policy makers, business and financial analysts, financial institutions, small and medium business owners as well as potential business owners. The findings of this study will assist SMEs to know the various loan profiles they can access from commercial banks, microfinance banks and other legal financial institutions to boost their capital base and profitability.

\section{B. Future Research}

This study is conducted on the extent to which SMEs access financial services especially loans and advances from commercial banks in order to growth their businesses in Ibadan metropolis. Further studies can be conducted on SMEs innovations and economic growth, SMEs roles on employment creation and other non-Financial challenges facing SMEs in other parts of the world.

\section{Recommendations of the Study}

Based on the findings of this study, the following recommendations are made:

i.commercial and microfinance banks should endeavour to offer financial services in form of loans and advances at affordable rate of interest with less stringent conditions to SMEs to grow their businesses.

ii. commercial and microfinance banks should monitor [15] closely the disbursement of loans and advances to SMEs to 
The Influence of Commercial Banks in Financing Small and Medium Enterprises (SMEs) in Nigeria: A Case Study of Fidelity Bank Plc and First Bank of Nigeria Plc in Ibadan Metropolis

ensure that the credit facilities are used for the purpose stated in the loan application form. ii.the quality control unit of the banks should put in place good bank customer relation with adequate feedback on services render to customers to enhance efficient service delivery.

\section{REFERENCES}

[1] Ayyagari and .... " Small and Medium Enterprises across the Globe (Small Business Economics)", 29, (2007) pp. 415-434.

[2] Demirgüç-Kunt, A., Beck, T. and Honohan, P. (2008). Finance for All? Policies and Pitfalls in Expanding Access. Washington, DC: The World Bank. Retrieved October 16, 2012, from http://siteresources.worldbank.org/INTFINFORALL/Resources/40 995831194373512632/FFA_book.pdf.

[3] European Commission, Communication from the Commission to the Parliament, the Council, the European Economic and Social Committee and the Committee of the regions (2016a). A European Agenda for the Collaborative Economy. (SWD) 184 final.

[4] C. Friedrich taking it personally: "The Crucial Success Factor for Small Businesses is its Entrepreneurs". Finance. Week, 51, December. 2004.

[5] R.N. Ime Challenges of Business Clustering in Nigeria: A study of Building Materials Businesses in AkwaIbom State of Nigeria. International Journal of Scientific Research and Engineering Development (2009). Vol. 2, Issue 1.

[6] B. KadiriI "Small and Medium Scale Enterprises and Employment Generation in Nigeria": The Role of Finance. Kuwait Chapter of Arabic Journal of Business and Management Review (2012). Vol.1 No. 9.

[7] V. Leopoulos Editorial. Prod. Plan Cont., 17(3): 225-228.

[8] A. Mina, H. Lahr, \& A. Hughes. (2013). The demand and supply of external finance for innovative firms. Industrial and Corporate Change, 22(4), (2006) pp. 869-901.

[9] T. A. Muritala, A.M. Awolaja and Y.A Bako, The Impact of Small and Medium Enterprises on Economic Growth and Development: America Journal of Business and Management, Vol. 1, No.1 (2012) pp 18-22.

[10] O.U. Ofili The Challenges Facing Entrepreneurship in Nigeria International Journal of Business and Management, Vol. 9, No.12 (2014) pp 258.

[11] Y.A Olorunfemi and J.A. Olajide. Small and Medium Scale Enterprises Financing and Economic Growth in Nigeria: Error Correction Mechanism. European Journal Globalisation and Development Research, Vol. 11, No.1 (2014)

[12] Oluba M. Sanusi tsunami: Wages of Financial Recklessness, The Spectator, August, $21-27$ (2009) page 15

[13] Olukayode and Somoye, (2013) The impact of Finance on Entrepreneurship Growth in Nigeria: Cointegration Framework. ACRN Journal of Entrepreneurship Perspectives. Vol. 2 Issue 2, (2013) pp. 21 - 45. ISSN 2224-9729

[14] A.B Onakoya, I.O Fasanya and H.D Abdulrahmanimpact of Financing Small Scale Enterprises on Economic Growth: European Journal of Business and Management, Vol. 5, No.4 (2013)

[15] Organisation for Economic Cooperation and Development (OECD) countries (2019). SME and Entrepreneurship Policy Outlook. www.oecd.org/sdd/business-stats. Retrieved online 12/05/2020

[16] Watson GEH (2004). A Situational Analysis of Entrepreneurship Mentors in South Africa. An Unpublished Dissertation submitted to the Department of Commerce and Business Management University of South Africa.

[17] Yolande. S and. Watkins J. A (2012) A Literature Review of Small and Medium Enterprises(SME) Risk Management Practices in South Africa African Journal of Business Management Vol. 6(21), pp. 6324-6330, http://www.academicjournals.org/AJBM 